\title{
The Role of Technological Advancement in Improving Food Security in Africa: A
}

\section{Review}

\author{
Desalegn Teshale Wolde*
}

Ethiopian Institute of Agricultural Research, EIAR Pawe Research Centre, Pawe, Ethiopia

*Corresponding author: Desalegn Teshale Wolde, Ethiopian Institute of Agricultural Research, EIAR Pawe Research Centre, Pawe, Ethiopia

\section{Abstarct}

Technological advancement has brought significant improvement in achieving food security in many parts of the world. This paper tries to review agricultural technology advancement on improving food security in African countries. Different literatures regarding to agricultural technologies which contributed to food security were reviewed. Public investments in scientific research across countries brought significant impact on the food security of its citizens. Notably Green Revolution had brought dramatic production increase mainly in Asian and Latin American countries. Despite its positive influence in Asian countries, African were not well benefited from technological advancement. Hence, little efforts were made in West Africa countries on NERICA rice varieties and in Uganda Mosaic virus resistant cassava varieties were taken as an example. Most recently many African governments showed their commitment to support the agricultural sector so as to boost the production and thereby achieve food security. According to the literatures reviewed diverse agro ecology's and farming system, rain fed dependent agricultural system, poor infrastructural development, limited knowledge and skills required by the technology were considered as the bottlenecks for achieving food security in Africa. Strengthen the capacity of research and scientific institutions to develop, generate and disseminate the technology could play crucial role in achieving food security. Besides strengthen technology adoption and extension services for smallholder farmers will have significant importance. Equally importantly access and provision of input and output markets, rural infrastructural development, credit access, development of irrigation canals and other issues shall be important policy directions that supports food security. Finally, creating regional or international integration enables countries to exchange, share and adopt technologies that ultimately increase production.

Keywords: Food security, agriculture, Technology, Africa

\section{Introduction}

The world's population is expected to be more than 9.7 billion in the coming thirty years, with nearly all of the growth occurring in the developing parts of the world particularly in sub-Saharan Africa and Asian countries. This population boom will be accompanied by increased strains on the food supply and resources, causing increased pressure on political and ecological systems, as well as threats to global security. These regions are experienced with poor agricultural production and productivity where it cannot feed the growing population.

For the last fifty years, scientific and technological advancement have benefited farmers by driving agricultural production in many parts of the world. Agricultural technologies have the potential to increase food availability through boosting crop productivity, increasing the supply and volume of food production per unit of agricultural land, sustaining the overall local and domestic food production [1]. Hence, generating appropriate agricultural technologies is among the most revolutionary and impact full areas of modern technology driven by increasing demand for food and feeding an ever-growing population. Improved technologies in agricultural sector can substantially increase the agricultural production and sustainability. Agricultural technologies refer to the improved management practices, improved and high yielding crop varieties, different agricultural machines and tools designed for improving in the agricultural production system [2]. Moreover, agricultural technology includes use of inorganic fertilizer, use of chemical like pesticides/insecticides, tilling the soil, irrigating land, cultivating crop, harvesting and threshing technologies, livestock feeding, etc. 
Increasing food production with the help of land, water, local seeds, fertilizer, and pesticides will not achieve the intended yield necessary to feed the increasing population. Hence, widespread use of local and advanced technologies and practices are critical to increase agricultural production and productivity [3]. Put differently, achieving the galloping food demand Via population growth by the conventional agricultural production might not work anymore which calls attention for agricultural technology advancement. However, access, availability and use of improved technologies into the hands of farming community is hardly possible. Swaminathan (2011) pointed that technological inaccessibility or unaffordability for the poor farmers has an impact on the efficiency of agricultural production. Due to this many smallholder farmers in developing countries particularly in Africa are not yet food secure. This paper tried to review the roles of technological advancement on achieving food security in Africa.

\section{Review Methodology}

This review paper focused on technological advancement on the food security issue in Africa. Hence, different available literatures on existing agricultural technologies were reviewed.

\section{Result and Discussion}

In this section different literatures regarding to technological advancement on food security, policy approaches and different issues were discussed. Besides, the existing opportunities and challenges were also discussed.

\section{Policy Approach on Technology Advancement}

Different literatures' show that by combining different agricultural technologies like zero tillage, conventional breeding, genetic modification, integrated soil fertility management, irrigation technology and different agronomic practices can boost the existing agricultural production. Hundreds of existing agricultural technologies and practices have the potential to boost agricultural yields in the developing world [4]. Technological innovations and improved farming practices are therefore helpful to increase agricultural production and productivity. Accordingly, African governments shall give due emphasis on the advancement of technologies mainly on drought tolerant seed varieties, drip irrigation, recommended usage and application of fertilizers, agrochemicals, agronomic practices like integrated pest management, conservation farming, and improved watershed and soil management.

African agriculture is characterized by low technology use and adoption coupled with different socioeconomic and institutional limitations for the sector. Despite the existence of agricultural research, science and training institutions in Africa, the capacity to generate, renovate and release agricultural technology is limited [5]. This might be the limited capacity of researchers due to educational system of the respective countries coupled with the limited allocation of public budget spent on research and development. Besides, poor infrastructural development, oversized and fragmented land use system, and outdated farming tools and or equipment were also contributing for low production in Africa. If agricultural technological development is not progressing, African agricultural production continues to experience low or stagnant productivity that leads to increasing food deficit and rising poverty and hunger.

A widely accepted objective for agricultural development in Africa is to achieve sustainable intensification with the adoption of new technologies such as improved high yielding seeds, inorganic fertilizer, irrigation technologies and natural resource management. These technologies improve land and labor productivity there by increasing yield. However, different reinforcing problems that is common in many African economies do not yet achieve food security. To mention some of the problems are poor infrastructures, poor human health, lack of well-developed monetary system, weak coverage of veterinary services, and thin agricultural markets. As a consequence, it has pressing challenges on the productivity of smallholder farmers [6]. The technology uptake of smallholder farmers, therefore, highly contribute to achieve food security. Hence, use of appropriate technologies can improve productivity and high volume of production both at household consumption and for increased household income [7].

Current literatures on the impacts of the technology adoption on food security in Sub-Saharan Africa (SSA) countries is quite limited. It usually lacks properly exploring the multiple aspects which characterize food insecurity. Many authors tried to derive conclusions on household food security indirectly by measuring, instead, the impact on household welfare [8], through monetary (income and expenditure) or production measures (farm production and yields). It showed that the effect of agricultural technologies would have significant impact to achieve food security.

The Comprehensive Africa Agriculture Development Program (CAADP) is Africa's policy framework for agricultural transformation, wealth creation, food security and nutrition, economic growth and prosperity for all. "Agriculture is everyone's business: national independence depends on its development because it enables us to escape the scourge of food insecurity that undermines our sovereignty and fosters

Citation: Desalegn Teshale Wolde*.The Role of Technological Advancement in Improving Food Security in Africa: A Review Op Acc J Bio Sci \& Res 7(1)-2021. 
sedition; it is a driver of growth whose leverage is now acknowledged by economists and politicians; it is the sector offering the greatest potential for poverty and inequality reduction, as it provides sources of productivity from which the most disadvantaged people working in the sector should benefit." Ibrahim Assane Mayaki, Chief Executive Officer of the NEPAD.

Another policy approach as pointed by Johanson and William (2007) is "Agricultural education and training has been demonstrated to be a vital, but much neglected, component of agricultural development in Africa. It is under-valued, under - resourced and under-provided. Human capital in agriculture has been depleted by long neglect." Hence, what would be necessary to improve agricultural productivity and food security in Africa is strengthening agricultural educational systems, more specifically the coverage and quality of higher education and research institutes. FAO [9] indicated that agricultural growth contributes not only to achieve to food security but also greatly supports poverty reduction. This might be many developing countries are agriculture dependent economy of which the sector is the main livelihood of citizens. Therefore, sustained and continues agricultural growth is very crucial for African countries.

\section{Technological Advancement Policy Issues Related to Food Security}

Globally accepted definition of food security is a situation where "all people, at all times, have physical and economic access to sufficient, safe and nutritious food to meet their dietary needs and food preferences for a productive and healthy life" [10]. In otherworld food security refers to the minimum level and availability of nutritionally adequate and safe food, and assured ability to acquire acceptable foods in socially acceptable ways.

Many African countries have adopted food security policy as one of their main national plans. This can be achieved through greater public investment in agriculture technology generation and innovation. Using the agricultural technologies, agricultural production and productivity would increase dramatically. Besides, technologies help conserving food by substantially reducing postharvest losses and food wastage, giving farmers access to real-time information and services in the field. In general, broader use of available technologies and improved management practices would have the following issues;

1. Help farmers to produce more grain, which improves their livelihoods and can provide food to the growing population.
2. Enhance safety and nutritional value of the food

3. Achieve agricultural sustainability through reduced resource use and climate friendly technologies.

Once we understood the wider use of technologies, different policy instruments are important to address and enhance the technology. Following this, many African governments have given due emphasis on technology generation, development and adoption, input subsidy including credit, rural infrastructural development particularly irrigation, market access both for the input and output, access to land and other resources.

\section{Opportunities and Constraints of Technological Advancement}

In many parts of the world particularly South and East Asia countries agricultural productivity has been growing rapidly, due to extensive use of new agricultural technologies. For millions of poor people, particularly in Asia, the technological advances of the Green Revolution (complemented by a massive increase in irrigation, chemical fertilizer and high yielding varieties) greatly supported for the reduction of poverty. As farm production increases, farm household's income and wages would be higher which leads to lowering the price of food, and hence generating new livelihood opportunities as the success in agriculture provided the basis for economic diversification [11]. Rapid technological advancement notably in the last 50 years leading to increased productivity in many parts of the developing world. Green Revolution that most Asian and Latin American countries used it as a vehicle to push out of poverty.

Agricultural technology advancement can reduce the risk of crop failures, safeguarding income of household food consumption and nutrition [12]. Hence, there is a positive link between agricultural technology and food security. Therefore, technologies enhance agricultural productivity gains and lower per unit costs of production, with the effects of raising the incomes of producers and of shifting outward the supply curve, which can lower food prices [13].

New and existing technologies to combat biotic and abiotic stresses, raise crop and livestock productivity, improve soil fertility and water available can potentially increase the amount of food production. Storage, refrigeration, transport and agro-processing innovations can address the different dimension of food accessibility. According to IFAD [14] report average cereal yield in developing countries increased by $2.7 \%$ per annum between 1966 and 1982. Particularly the performance in South Asia 
was quite impressive, where, between the mid-1960s and the mid-1980s, wheat yields increased by $240 \%$ and those of rice by $160 \%$ [15]. Even though rice and wheat were impact full crops during Green revolution, gain from new technology have also occurred in other crops and regions with increased investments in agricultural research and extension service.

Development and release of modern varieties have been impressive in many of the developing countries. Byerlee [16] estimated that $74 \%$ of rice, $70 \%$ of wheat and $57 \%$ of maize grown in developing countries were improved or modern varieties. Even though these seeds are outputs of the green revolution with its ingredients (HYV, fertilizer and irrigation), substantial proportion of these improved or modern seeds are grown with low or no inputs [17]. This might be taken as an additional attribute of the modern seeds. According to the reports of the world bank [18], the average cereal yield in the early times of Green Revolution (around 1961) was 1 ton per hectare in the developing world (around 1961) and the productivity rose to 3 tons per hectare in 2000. Regionally, East Asia and the Pacific increased to 4.5 tons per hectare, Middle East and North Africa increased to around 2.3 tons per hectare, while subSahara countries are stagnated around 1 ton per hectare.

In 2000, the area under improved cereal varieties coverage was $84 \%$ in East Asia and Pacific, 61\% in Middle East and North Africa and Latin America and the Caribbean, while in Sub-Sahara countries the area covered by improved cereal crops were only $22 \%$. In 2002 , fertilizer consumption had reached $190 \mathrm{~kg}$ per ha of arable and permanent crop land in East Asia and Pacific, $73 \mathrm{~kg}$ in Middle East and North Africa, but Sub-Saharan countries fertilizer consumption was less than $13 \mathrm{~kg}$. Here fertilizer is taken as one of the agricultural technologies that can boost productivity. Given available technologies at a hand, the farmers ability or level of technology adoption is limited.

Around 1961, average cereal yields were around 1 ton per ha in the developing world, and rose to nearly 3 tons per ha by 2005. They increased to around 4.5 tons in East Asia and the Pacific (EAP), to around 2.3 tons in the Middle East and North Africa (MENA), while they stagnated around 1 ton in SSA [18]. Even though a number of technologies can play a significant role in addressing food security, African countries mainly sub-Saharan region has yet food insecure. This region has many challenges of productivity than any other region of the world; more diversified agroecology, and more crop and livestock pests and diseases than elsewhere. There are no dominant farming systems that extend over very large areas such as irrigated rice and wheat in Asia.
Irrigation infrastructure is poorly developed. Climate change will significantly add to the technology challenge. As a consequence of these factors, Africa is less able to borrow technology from other tropical countries; and technology transfers between regions in Africa are also constrained. Unlike Asian, African green revolution was partly on noncereal crops like mosaic virus resistant cassava varieties released in Uganda [19].

Recently many African countries showed their commitment to boost the agricultural productivity with due emphasis on investment of science and technology. Through plant breeding techniques producing high yielding and disease, pest and drought tolerant crop varieties. These techniques can be hybridization, molecular-marker assisted selection, agricultural biotechnology, crop protection solutions and other technologies that enhance the quality and quantity of the yield. Increasing yield reduced hunger, it further leads more income, then less poverty. On the contrary technology advancement may not necessarily help poor farmers in real terms. If a country is nationally food secure, this might not necessarily mean all citizens at the household level are food secured.

The ingredients of green revolution in India were successful to increase the yield at the national level. These ingredients are affordable to those who are relatively rich farmers. Shiva (1993) as cited by Kathryn Sebby (2010) the Green Revolution favored for the rich who are endowed with best farm areas; hence they can afford expensive technological investments for. High yielding crop varieties are dependent on expensive inorganic fertilizers, pesticides, herbicides and it also requires knowledge and skills associated with use of these technologies. This large volume of fertilization and chemical use leads to serious environmental issues like salinization problem. Further they forced to sell their land and other assets to afford the technology of the Green Revolution [20]. This clearly showed poor small farmers were far away from the benefits of the Green Revolution and even worse off.

Rashid [21] summarized the futurities of Green Revolution in India; high initial outlay, since most of poor farmers were tenant farmers they have little or no money to buy seeds, fertilizer, fuel, machinery, inappropriate irrigation schemes that cause the environment, unemployment getting higher because of mechanization which leads to other social crisis, caused regional disparities as Green Revolution purposively implemented where water supply, large fertilizer access and farm credit were assured. As consequence India's first Green revolution which was launched to ensure food security as there was severe food 
shortage by focusing mass production, was ended by the above-mentioned failures. Hence the country left behind achieving food security at household level.

Even though technological advancement has been registered achievement, hunger and poverty continue to be common phenomenon in the developing world. The problem is particularly acute in areas of the world dependent upon rain-fed agriculture, in particular subSaharan Africa, where the impact of new technologies has been less apparent and agricultural productivity has at best stagnated, and may even have fallen in some areas [22]. Widespread use of advanced technologies and practices is critical to intensifying food production in an environmentally sustainable manner, but the situation for food-insecure smallholder farmers is exceptionally risky, making them averse to experimentation [3]. Technology adoption is inhibited due to social, economic and political situation of a given many sub-Saharan countries. Hence, technologies exist, at least some, diffusing it for the poor farmers to enhance the productivity is a critical challenge [23-25].

\section{Recommendation and Conclusion}

As world population is increasing achieving food security is key issue in the 21st century. Modernizing the agricultural sector is prime objective, as the sector is main satay in many food insecure countries where population growth exceeds their economic growth. Therefore, food security without continuous and innovative technology development would have been unimaginable. African governments should create enabling policy environment on most promising research and technology innovations that further improve farm productivity. Understanding the technology and its complexity of adoption strategy must be given due attention. Since full range of scientific research both social and natural sciences are key to solve food insecurity challenges, African countries should invest on research and development [26-28]. Removing barriers that prevent technological advancement and adoption of the technology for the poor farmers is crucial, equally importantly secure input and output markets, rural infrastructural development, providing credit, constructing irrigation canals and other issues shall be policy directions that significantly supports food security. Creating regional or international coordination enables countries to exchange and adopt technologies among them [29].

Agricultural technology advancement in Africa not only boost agricultural productivity but also supports its profitability, sustainability and hence ensure food security as well as obtaining the full range of nutrients [30]. Therefore, to make these technologies impact full support policies have to be developed for effective technology transfer and extension programs that ultimately focus on smallholder farmers' productivity

\section{References}

1. Feder G, Just RE, Zilberman D (1985) Adoption of agricultural innovations in developing countries: A Survey. Economic Development and Cultural Change 33(2): 255-298.

2. Abdul A, Luan J, Rafia K, Imran H (2016) Modern agricultural technology adoption its importance, role and usage for the improvement of agriculture. American-Eurasian Journal of Agriculture and Environmental Sciences 16 (2): 284-288.

3. Paul W, Anna W (2015) Technological advances to improve food security: Addressing challenges to adoption. Research Brief RTI Press Publication.

4. Vanessa M (2012) Agricultural technologies for food security, or something more? Climate change, agriculture and food security conference report Rio Brazil.

5. Hans PB (2009) Challenges and opportunities for African agriculture and food security: High food prices, climate change, population growth, HIV and AIDS. expert meeting on How to feed the world in 2050. Food and Agriculture Organization of the United Nations Economic and Social Development.

6. Kirsten JF, Dorward Andrew, Poulton C, Vink N (2009) Institutional Economics Perspectives on African agricultural development. International Food Policy Research Institute Washington, DC.

7. Kassie M, Moti J, Shiferaw B, Mmbando F, De Groote H (2012) Improved maize technologies and welfare outcomes in smallholder systems: Evidence from application of parametric and non-parametric approaches. selected paper IAAE Triennial conference, Brazil, August, 18-24.

8. Bezu S, Kassie G, Shiferaw B, Ricker-Gilbert J (2014) Impact of improved maize adoption on welfare of farm households in Malawi: panel data analysis. World Development 59: 120-131.

9. FAO (Food and Agricultural Organization) (20019) Challenges and opportunities for African agriculture and food Security: Expert meeting.

10. FAO (Food and Agriculture Organization) (1996) World food summit plan of action. Rome, Italy.

11. Timmer C.P., (1988) The agricultural transformation. Hand book of Development Economics 1(1).

12. Cavatassi R, Lipper L, Narloch U (2011) Modern variety adoption and risk management in drought prone areas: Insights from the sorghum farmers of Eastern Ethiopia. The Journal of the International Association of Agricultural Economics 42(3): 279 $-292$.

13. Kassie M, Shiferaw B, Geoffrey M (2011) Agricultural technology, crop income, and poverty alleviation in Uganda. World Development. 39(10): 1784-1795.

14. IFAD (International Food and Agricultural Development), Rural Poverty Report (2001) Oxford, UK.

15. Kerr J, Kolavalli S (1999) Impact of Agricultural research on poverty alleviation: Conceptual framework with illustrations from the literature. EPTD Discussion Paper No. 56.

16. Byerlee D (1996) Modern varieties, productivity and 
sustainability: Recent experience and emerging challenges. World Development 24(4): 697-718.

17. MP Reynold SNE (2006) Borlaug, Impacts of breeding on international collaborative wheat improvement. Journal of Agricultural Science 144: 3-17.

18. WB (World Bank), (2007), Cultivating knowledge and skills to grow African agriculture. A synthesis of an institutional, regional, and international review. Report no. 40997-AFR.

19. Felix I. Nweke, Dunstan S. C. Spencer, John K. Lynam, The cassava transformation: Africa's best kept secret.

20. Kathryn Sebby (2010) The Green Revolution of the 1960's and its impact on small farmers in India. Environmental sciences undergraduate student theses, University of Nebraska, Lincolin.

21. Rashid F (2010) Indian Green Revolution: Success, Failure and Second Green Revolution. Rashids Blog an educational portal.

22. DFID (Department for International Development) (2016) Technologies for international development. United Kingdom.

23. Ben Ramalingam (2016) Kevin Hernandez, Pedro Prieto Martin, Becky Faith, Ten frontier technologies for international development. Institute of development studies

24. Chirwa E (2005) Adoption of fertilizer and hybrid seeds by smallholder maize farmers in southern Malawi. Development South Africa 22(1): 1-12.

25. Grain Briefing (2009) Nerica, Another Trap for Small Farmers in Africa.

26. Ibrahim AM (2011) Chief executive officer of new partnership for development (NEPAD): Interview during planning and coordination, New York, USA.

27. Kabunga NS, Dubois T, Qaim M (2014) Impact of tissue culture banana technology on farm household income and food security in Kenya. Food Policy 45: 25-34.

28. Kassie M, Teklewold H, Jaleta M, Marenya P, Erenstein O (2015) Understanding the adoption of a portfolio of sustainable intensification practices in eastern and southern Africa. Land use policy 42: $400-411$.

29. UN (United Nations) (2017). The Role of science, technology and innovation in ensuring food security by 2030. Report of the secretary general, commission on science and technology for development twentieth session, Geneva, Switzerland.

30. Yongate P, Seonwoo K (2005) Linkage between knowldege management and R\&D management. Journal of Knowledge Management 9(4): 34 -44.

*Corresponding author: Desalegn Teshale Wolde, Email: desiteshale@gmail.com

Next Submission with BGSR follows:

- Rapid Peer Review

- Reprints for Original Copy

- E-Prints Availability

- Below URL for auxiliary Submission Link: https://biogenericpublishers.com/submit-manuscript/ 